\title{
FAILED COLLABORATION AND QUEER LOVE IN YEATS'S THE CAT AND THE MOON AND BECKETT'S ROUGH FOR THEATRE I
}

\author{
Alexandra Poulain \\ Sorbonne University, FR
}

\begin{abstract}
Beckett's Rough for Theatre I, first written in French in the late 1950s, picks up the theme of Yeats's The Cat and the Moon-itself based on earlier material, including Synge's The Well of the Saints. Staging mutually dependent disabled bodies and charting the elaboration of joint poetic vision, both plays also paradoxically focus on the dramaturgical and poetic potential of collaborative failure. While Yeats insisted that his play should be read allegorically as a dramatisation of the journey towards Unity of Being, this paper attempts to take it at face value, alongside Beckett's sequel, reading them both as dramas of (failed) collaboration between disabled, mutually complementary bodies. More specifically, it argues that despite Yeats's best effort to allegorise the grotesque bodies on the stage into abstract principles of Body and Soul, something in his play refuses to be subsumed into allegory and resists the play's drive towards unity. This resistant "something" has to do with the queer (in every sense) version of love which is being played out on the stage, and it is precisely this queer, sadomasochistic, unproductive love, and the jouissance it procures, uncomfortably, for two disabled characters, which becomes the central theme of Beckett's play. Further, the paper suggests that this motif of queer love doubles as a paradigm for an alternative form of literary collaboration, one which is not geared towards the actual production of a finished marketable product such as a book or a play, but rather towards the shared creation and immediate enjoyment of stories invented and performed in a space removed from, yet marginal to, the sphere of modern capitalistic exchange.

Keywords: Yeats; Beckett; The Cat and the Moon; Rough for Theatre I.
\end{abstract}

\footnotetext{
${ }^{*}$ Professor of postcolonial literature and theatre at the University of Paris 3 - Sorbonne Nouvelle (France). She has published widely on modern and contemporary drama and performance, with a special focus on Yeats and Beckett. Her new book Irish Drama, Modernity and the Passion Play (Palgrave, 2016) looks at rewritings of the Passion narrative as a modality of political resistance in Irish plays from Synge to the present day. She is President of the International Yeats Society and Vice-Chair for Europe of IASIL (International Association for the Study of Irish Literatures). Her e-mail address is poulain.al@orange.fr.
} 
In the note to the 1934 edition of The Cat and the Moon, his stage version of the tale of the blind man and the lame man, Yeats is keen to gloss its allegorical meaning and makes the point that at the time of writing, he "kept in mind, while only putting the vaguest suggestion of it in the play, that the blind man was the body, the lame man was the soul." Bemoaning the philosophical ineptitude of the "populace", he adds that in writing the final lyric about the cat and the moon he "allowed [himself] to think ... of the cat as the normal man and of the moon as the opposite he seeks perpetually", a quest for unity finally realised in the drama after the two protagonists have gone their separate ways and "the lame man takes the saint upon his back" (Var. Pl. 807). Despite Yeats's invitation to read the play allegorically, I want to take my cue from the undiscerning populace and take the play, alongside Beckett's Rough for Theatre I (which rewrites Yeats's earlier play) at face value, reading them as dramas of (failed) collaboration between disabled, mutually complementary bodies. More specifically, I want to argue that despite Yeats's best effort to allegorise the grotesque bodies on the stage into abstract principles of Body and Soul, something in his play refuses to be subsumed into allegory and resists the play's drive towards unity. I will offer that this resistant "something" has to do with the queer (in every sense) version of love which is being played out on the stage, and that it is precisely this queer, sadomasochistic, unproductive love, and the jouissance it procures, uncomfortably, for two disabled characters, which becomes the central theme of Beckett's play. Further, I will suggest that this motif of queer love doubles as a paradigm for an alternative form of literary collaboration, one which is not geared towards the actual production of a finished marketable product such as a book or a play, but rather towards the shared creation and immediate enjoyment of stories invented and performed in a space removed from, yet marginal to, the sphere of modern capitalistic exchange.

In 1917, shortly before getting married, Yeats wrote a comic "play for dancers", The Cat and the Moon, which he nevertheless decided not to include in the volume Plays for Dancers "as it was in a different mood", as he explained in a note when the play appeared in print in The Cat and the Moon and Certain Poems in 1924. ${ }^{1}$ Yeats mentions that he "intended [his] play to be what the Japanese call a Kiogen", a form which Yoko Sato defines as "a traditional Japanese farce or comedy, performed 'between' Noh plays, or 'within' a Noh play” (27). Indeed he was partly inspired by the Japanese Kyogen Kikazu Zato, which featured in the Fenollosa manuscripts which Yeats had discovered through Pound. While Kikazu Zato features a comically dysfunctional couple formed by a blind man and a deaf man, Yeats's play adapts some of the formal elements from Kyogen but features a Blind Beggar and a Lame Beggar, and thus produces his version of an old popular folktale which runs through both Western and Eastern traditions. In characteristically disingenuous fashion, Yeats claims in the 1924 note that " $[w]$ hen I had finished, I found them [the blind man and the lame man] in some medieval Irish sermon as a simile of soul and body, and then that they had some like meaning in a Buddhist Sutra" (Var. Pl. 807). He fails to mention, however, that his main source of inspiration was Synge's 1905 play The Well of the Saints, itself 
inspired by a late fifteenth century French morality play, Andrieu de la Vigne's $L a$ Moralité de l'Aveugle et du boiteux, which Synge had come across during his stay in Paris in 1895-96. While The Well of the Saints freely adapts the French play and focuses on a married couple of blind beggars, The Cat and the Moon returns to the original cast of a lame man and a blind man. Like De la Vigne's morality play as well as earlier folk versions of the story, Yeats's play revolves around the idea that with their respective infirmities they are, theoretically at least, ideally suited to complement each other, the blind man carrying the lame man on his back, lending him his legs while the lame man guides him and lends him his eyes, each serving as a prosthetic extension of the other. This makeshift arrangement lasts for forty years, until the pair encounters a saint who offers either to cure them or to bless them. Blind Beggar chooses to be cured, recovers his sight, confounds Lame Beggar for stealing his black sheep and leaves after giving him a sound beating. Lame Beggar opts for the saint's blessing, takes him on his back and, in the revised ending of 1931, miraculously exits dancing.

The Cat and the Moon is driven by a teleology of unity and wholeness, and yet, I will argue, what makes the play a great play is that it resists this teleology and ultimately deflects our modern, ableist expectations that aberrant bodies will be normalised. As we have seen, Yeats returns to the original folktale and its cast of two disabled characters, a blind man and a lame man, who join forces in order to remedy their respective physical weaknesses and survive in a world where the disabled are not catered for by the community of normals. The dialogue makes it clear that their primary motivation for teaming up is the need to secure food, as Lame Beggar reminds his acolyte:

When you go out to pick a chicken, or maybe a stray goose on the road, or a cabbage from a neighbour's garden, I have to go riding on your back; and if I want a goose, or a chicken, or a cabbage, I must have your two legs under me." (Var. Pl. 795)

The detailed, longing evocation of mundane foods, culminating with the anticlimactic "cabbage", belongs in the register of farce, yet no-one in an Irish audience would dismiss fear of hunger as an issue to be made light of. What is at stake here, unambiguously, is survival. Unlike the independent, unified, sovereign subject conceptualised by the philosophers of the Enlightenment as the universal subject of modernity, Lame Beggar and Blind Beggar are incomplete and mutually dependent, and their survival is made possible only by the couple which they form on the margins of the social order. The drama thus offers a space to this alternative community of two, yet works very hard to absorb their alterity into normality.

In fact, this tendency is initiated in De la Vigne's 1496 morality play, which turns the folktale into a Christian parable and introduces the idea of the cure. In La Moralité de l'aveugle et du boiteux, the pair encounters a procession carrying the relics of St Martin, and both are made whole: the lame man declines at first, 
preferring to beg rather than work, and curses St Martin when he finds himself cured anyway; the blind man recovers his sight and praises God. Thus by the end of the play, the alternative community of freaks has been satisfyingly absorbed into normal society, and a Christian moral emerges, whereby the spiritually enlightened blind man is rewarded for his faith, while the miscreant lame man is punished for failing to recognise the blessing bestowed unto him. Alternatively, one might argue that a kind of ableist justice is being dealt out, which rewards the blind man for wanting to conform to the bodily standards of the able-bodied, and punishes the lame man for preferring to remain different.

In The Cat and the Moon, Yeats embraces this paradoxical reading of the earlier play: in his version Blind Beggar, who asks for his sight rather than for the saint's blessing, contradicts the topos of the visionary blind man. He is the more materialistically-minded of the pair, and it is Lame Beggar who, counterintuitively, declines the offer of the cure and opts for spiritual rather than physical integrity. Yet the blessing allows him to transcend his physical limitations, and in the revised ending he exits dancing jubilantly, so that again, dissident bodies are conveniently restored to normality. In this sense, Yeats's drama conforms to the modern ableist ethos which posits that normality is always desirable, and yearns to cure disabled bodies rather than accommodate them, physically and symbolically, within the space of social exchanges. As Lennard J. Davis points out, "The alterity presented by disability is shocking to the liberal, ableist sensibility, and so narratives involving disability always yearn for the cure, the neutralizing of the disability" (99). One might add that this "ableist sensibility" also serves a capitalistic agenda which aims to turn disabled bodies into working, productive bodies. ${ }^{2}$ Yeats takes this "neutralizing" agenda further by turning the materiality of the grotesque, disabled bodies of the beggars into abstract allegorical principles of body and soul: the play thus invites us to see the crippled pair as the stylised representation of "a normal man", in itself a figure of incompletion in Yeats's philosophical system which posits man as perpetually in quest of his opposite. In The Cat and the Moon, however, the inconceivable reunion of opposites is miraculously achieved at the end of the play, when the allegorical pair of Blind Beggar and Lame Beggar is superseded by the more satisfactory pair of Lame Beggar and Saint, symbolising Unity of Being. Extraordinary symbolic violence is thus deployed in order to "neutralize" the disturbing alterity of incomplete, non-standard bodies and promote instead what I have called a teleology of unity.

Yeats, however, suspected that his allegory might be rather too subtle for the unenlightened multitude to grasp. A more generous reading would offer instead that the allegory works precisely because there is more to the play than abstract principles, because it largely fails to neutralise the grotesque bodies and jarring voices of the characters which insist on being seen and heard. When the cured Blind Beggar threatens to give him a thrashing, Lame Beggar tries to dissuade him: "Don't lay a hand on me. Forty years we've been knocking about the roads together ..." (Var. Pl. 802). The reality of these forty years of companionship is made perfectly palpable in the ten or twenty minutes that the play lasts: the 
constant physical intimacy in which their mutual dependence is grounded, the burlesque philosophising and unceasing bickering, and the violence inherent in their relationship, with Lame Beggar routinely stealing from his acolyte, and Blind Beggar retaliating by beating him up whenever possible. They are like an old married couple, who may delude themselves that they have spent a lifetime together only because they had no other choice, but who obviously find a degree of enjoyment in their daily exchange of stories and blows. Collaboration-the rational arrangement by which they decide to join forces in order to find food and survive-is superseded by the unproductive jouissance produced in their disturbing, unruly performance of what we must resolve ourselves to call love.

The "marriage" motif is made candidly explicit when the Saint, speaking in the voice of First Musician, addresses Blind Beggar: "I am a Saint and lonely. Will you become blessed and stay blind and we will be together always?" (Var. Pl. 798). This may not be a completely orthodox proposal, yet the affective dimension is prominent ("I am lonely") and the end of the speech ("together always") mimes the diction of wedding vows. Blind Beggar declines politely, but Lame Beggar takes up the offer and the union is consummated when he takes the Saint upon his back, and finds that he doesn't "weigh more than a grasshopper"3 (Var. Pl. 803), Thus the materiality of bodies and the sheer jouissance of storytelling and bickering, fiction and friction (to paraphrase Stephen Greenblatt), produced in the prolonged intimacy of Blind Beggar and Lame Beggar, are dissolved into metaphor in the spiritual union of Lame Beggar and Saint, and the final dance celebrates the transcendence of bodily limitations and the attainment of Unity of Being.

However, there is yet a third queer couple which hovers on the margins of the play, and is not displaced, allegorised or danced away. It does not appear on the stage, but in one of the stories exchanged between Lame Beggar and Blind Beggar as they make their slow progress towards the Saint. I quote at length:

BLIND BEGGAR. Do you mind what the beggar told you about the holy man in the big house at Laban?

LAME BEGGAR. Nothing stays in my head, Blind Man.

BLIND BEGGAR. What does he do but go knocking about the roads with an old lecher from the county of Mayo, and he a woman-hater from the day of his birth! And what do they talk of by candle-light and by daylight? The old lecher does be telling over all the sins he committed, or maybe never committed at all, and the man of Laban does be trying to head him off and quiet him down that he may quit telling them.

LAME BEGGAR. Maybe it is converting him he is.

BLIND BEGGAR. If you were a blind man you wouldn't say a foolish thing the like of that. He wouldn't have him different, no, not if he was to get all Ireland. If he was different, what would they find to talk about, will you answer me that now? (Var. Pl. 797). 
As Blind Beggar explains, the couple formed by the "holy man" and the "old lecher" is grounded on the jouissance both partners derive from the unresolved dialectics of their relationship, with the "old lecher" telling outrageous stories of his sexual exploits and the "holy man" trying (but failing) to shut him up. The couple provides the conditions for the production of fiction, in an asymmetrical configuration which anticipates many of Beckett's couples, with one partner cast as Storyteller and the other as Listener. Again the jouissance of fiction is enhanced by the thrill of constant friction; yet if the "holy man" remonstrates, Blind Man suggests that he does not in fact want to "convert" the "old lecher", which would bring their mutual enjoyment to a close: this couple, unlike the others in the play, resists dialectical resolution. The passage is more explicitly sexual than any other in the play and facetiously rewrites Catholic confession as homosexual play: it does not matter if the stories told by the "old lecher" are true or not ("all the sins he committed, or maybe never committed at all"), as long as they are salacious and provide mutual pleasure. The queer motif (also encoded in the ambiguous term "converting") is even more explicit in the 1924 version of the play (as published both in The Criterion and in The Cat and the Moon and Certain Poems), which reads: "Did you ever know a holy man but had a wicked man for his comrade and his heart's darling?" (Var. Pl. 797).

The passage may be a little cryptic, yet to Yeats's more informed contemporaries it would have been a transparent allusion. In the note to the 1934 edition, Yeats gives the game away: "The holy man in the big house . . . and his friend from Mayo were meant for Edward Martyn and George Moore, both of whom were living when the play was written" (Var. Pl. 808). He then suggests that in a production where the audience is unlikely to get the allusion, the passage should be omitted altogether. Martyn and Moore thus feature as the real-life paradigm for the fictional couple of Blind Beggar and Lame Beggar. Reading Moore's evocation of their trips to Bayreuth in Hail and Farewell, Adrian Frazier describes them as "ill-assorted art-lovers", and comments: "One infers the attraction between them from all the evidence of things that should drive them apart and don't" (21-22). In making Martyn and Moore the butt of his joke, and in resorting to the very Wildean practice of encrypting a gay allusion decipherable only to the initiated, Yeats reveals the degree to which he was himself implicated in a triangle of ambiguous affects. As Frazier points out: "In Ave Moore gives a description of his friendships [with Martyn and Yeats] that makes them sound more than homosocial, less than homosexual" (20). The play thus throbs with an intricate entwining of queer desires which hark back to aberrant bodies that resist absorption into allegory and thus derail the play's unifying teleology. As a literary couple, Martyn and Moore were remarkable for their failure to create collaboratively. F. S. L. Lyons provides a terse rendering of their "unhappy partnership" of 1900 "when, after a short, sharp struggle, a play which had begun as The Tale of the Town by Edward Martyn emerged as The Bending of the Bough, by George Moore" (17). Yet in Yeats's rendering of their couple, failed collaboration (understood as the failure to produce a finished work, 
a marketable book or play) is reconceptualised as the successful, shared jouissance of fictionalising, the telling and hearing of stories that offend and delight in the marginal space of queer intimacy.

It is thus fitting that "the holy man" and "the old lecher" should appear in a story which circulates among beggars and cripples, on the margins of the community of normals into which Blind Beggar and Lame Beggar are ultimately absorbed. In the original version of the play, Blind Beggar merely tells the story to Lame Beggar: "Did you ever know a holy man..."; but in the revised text of 1934, he mentions it as a story told and retold within a wider community of beggars: "Do you mind what the beggar told you about the holy man...". Blind Beggar is ultimately cured and reclaimed by the community of able-bodied productive workers, and Lame Beggar is relieved of the materiality of his aberrant body and subsumed into a metaphor of spiritual wholeness; but the persistence of queer desires and queer stories on the margins of the social order testifies to the limits of this neutralising, normalising agenda, and proposes an alternative paradigm of failed collaboration as unproductive, highly successful jouissance. In resisting both allegory and absorption into normalcy, queer disabled bodies ultimately challenge the ethos of modern bourgeois capitalism, grounded as it is in the imperatives of production and reproduction. Martyn and Moore are jokingly co-opted into the marginal community of freaks who fail to comply with the demands of modern productivity, and continue to indulge in the decidedly nonmodern erotics of storytelling.

In the late 1950s, Beckett returned the story of the Blind man and the Lame man to the French language with Fragment de Théatre I, later translated into English as Rough for Theatre I. Beckett of course was very familiar with Yeats's primary source for The Cat and the Moon, Synge's The Well of the Saints, which he saw at the Abbey Theatre before he left Dublin; indeed when his biographer James Knowlson asked him to name his theatrical influences "he suggested only the name of Synge" (71). However, whether or not Beckett attended the Dublin Drama League's premiere production of The Cat and the Moon at the Abbey Theatre in May 1926, he was also keenly aware (though often sceptical) of Yeats's work for the theatre. The similarities between Yeats's comic "play for dancers" and Beckett's Rough for Theatre I are striking enough to allow us to read the latter as (partly) a parody of the former. ${ }^{4}$ Like Yeats, Beckett returns to the original story of the blind man and the lame man and amplifies the queer undercurrent we have identified in The Cat the Moon; but in his darkly secular version two incomplete bodies can never hope to transcend their shortcomings and achieve unity, and their attempt at collaboration is reduced to a brief, catastrophic encounter. The slippage from failed collaboration to the shared, unproductive jouissance of storytelling, adumbrated in Yeats's play, is the central focus of Rough for Theatre 1, aptly titled, in the French version, Fragment pour le théatre. This title points to the fragmentary nature of the piece, of course, which is itself a meditation on fragmentariness, or resistance to completion. The word "fragment" (from the Latin frangere, to break) also suggests the 
violence with which something is shattered into pieces, and thus anticipates the violent climax of the play.

While The Cat and the Moon picks up motifs from the comic subplot between the Blind Man and the Fool in On Baile's Strand, Rough for Theatre I recycles many aspects of Endgame, but Hamm's infirmities in the earlier play are distributed between $\mathrm{A}$, a blind beggar first seen scraping his fiddle besides "ruins" on a street corner, and B, a wheelchair-bound, pole-propelled cripple who encounters A on one of his rare ventures away from his dark room and suggests that they should team up, only to destroy all chances of a successful collaboration when he whacks the overenthusiastic A with his pole. The "fragment" ends in an impasse with $\mathrm{B}$ threatening to deprive the disoriented $\mathrm{A}$ of his fiddle, and A wrenching the pole from B's grasp. With its brief explosion of violence followed by a sardonic, inconclusive outcome, the play only relates ironically to the possibility of a utopian alternative to modern capitalistic sociality, and ultimately shatters what brief hope we may have fostered.

Beckett's Rough rewrites Yeats but does away with the Yeatsian fantasy of recovered unity. For A (a blind old fiddler) and B (an older wheelchair-bound cripple), there is no saint and no hope of a cure. They are stuck with what they are, suffering bodies in an earthly world which adjoins no dream-world, and Beckett's deployment of Yeats's mystical lexicon is purely to parodic purposes. As $B$ remarks when he first appears, attracted by the sound of A's discordant music: "So it is not a dream. At last! Nor a vision, they are mute and I am mute before them" (CDW 227). The emphatic diction ("it is not a dream", "At last!") mimics romantic fervour to sardonic effect, given the appalling state of both protagonists, while the coda, which may be addressed primarily to A but implicitly breaks through the fourth wall and takes in the dismayed, "mute" audience as well, invites us to take the whole speech as a dramaturgical comment about this most un-Yeatsian play: "it is not a dream"- "nor a vision." Nor, indeed, an allegory: when B suggests he and A should team up to fend off hunger, he tempts him with variously appealing prospects:

B: Do you like company, Billy? [Pause] Do you like tinned food, Billy?

A: What tinned food?

B: Corned beef, Billy, just corned beef. Enough to keep body and soul together, till summer, with care. (CDW 227)

Whether or not this was in fact intended by Beckett, the passage provides a scathing counterpoint to Yeats's allegorical treatment of his characters, whereby "the blind man was the body, the lame man was the soul", and uses bathos to undermine any such reading of this play: in Beckett's disenchanted world "corned beef" is apparently more valuable than "company", and the spiritual degradation which this signals is reflected in the catachrestic state of language itself, where "keeping body and soul together" really means keeping the body going, never mind the 
soul. A and B are suffering, hungry bodies, not allegories of abstract entities-nor do they allegorise "the human condition": while we may recognise something of our intrinsic vulnerability in them, as disabled, dependent characters they are nevertheless barred from participation in modern society as grounded in the Kantian fiction of the sovereign, autonomous subject of universal law. As Lennard J. Davis puts it tersely, writing about the way in which Enlightenment writers conceptualised normalcy as a prerequisite for the possibility of representative democracy: "Democracy needs the illusion of equality, and equality needs the fiction of the equal, or average, citizen" (110). The nameless A and B, however, are less equal than others, and hardly qualify as "citizens", or subjects under the law. They demand to be seen and heard for what they are, damaged, pathological subjects who strive for survival and form an alternative community of two where each serves as the prosthetic extension of the other:

B: Of course if you wish me to look about me I shall. And if you care to push me about I shall try to describe the scene, as we go along. (CDW 230)

As in The Cat and the Moon, one major reason for A and B to join forces is to enhance their chances of finding food. Yeats's pastoral grotesque has degenerated into Beckett's post-industrial burlesque, and baked beans and corned beef have replaced the sturdier foods of country life; yet Beckett's Rough takes its place in a long line of post-Famine Irish plays harrowed by fear of hunger. However, as in The Cat and the Moon, the urge to find food is also partly a screen for less mundane motivations. As we have seen, B's first impulse is to entice A with the promise of "company", not "tinned food". Although A at first takes no interest in this, the quest for "company" - call it companionship, solidarity, or love-is in fact central to the play. Even before addressing A, B muses that they might "join together and live together, till death ensue" (CDW 227). Beckett parodies Yeats parodying marriage vows, and gleefully builds on the queer subtext of the earlier play, so that Rough is laden with unmistakable erotic overtones. For all his gruffness B reiterates his proposal in a number of mock-sentimental platitudes"Do you think we would make a match, now you are getting to know me?" (CDW 229), "If you ask me we were made for each other" (CDW 229) - until A finally accepts the proposed union. This turns out to be a sequence of sadomasochistic power games not unlike those played out by Hamm and Clov in Endgame, with B barking out orders and A trying, and failing, to comply. Towards the end of the piece, after B has hit A with his pole, A nevertheless accepts to "straighten [B's] rug", kneels down in front of B's wheelchair and proceeds to feel his way up his body, repeatedly gasping "What hands you have", and to B's exasperation, laying his head on B's knees (or "knee", as the one-legged B corrects). The scene is disturbing precisely because this awkward, maladjusted couple resists unity, which we are culturally and aesthetically programmed to wish for. According to Plato's myth of the origin of Eros, as told (hilariously) by Aristophanes in the Symposium, human beings were originally spherical, but when they became 
arrogant and threatened the dods' supremacy Zeus sliced them in two, so that we are now forever in search of our other half-a conception still pervasive in modern culture, and reflected in B's clichés ("we were made for each other"). In eroticising the fable of the blind man and the lame man, both Yeats and Beckett implicitly solicit the Platonic myth and resist its implications: their couples of disabled men fail to make a perfect whole. In The Cat and the Moon, the Saint's intervention provides a way out of this impasse, suffering bodies are dissolved into allegory and Unity of Being is achieved - yet as we have seen, the story of the holy man and the old lecher continues to offer a queer counter-narrative of enduring, conflict-ridden love. In Rough, Beckett picks up the theme and gives it centre stage, forcing upon the "mute" audience the inconceivable spectacle of queer, disabled, violent eroticism. Because A and B's bodily deficiencies (by ableist standards) are foregrounded much more realistically, and thus uncomfortably, than in Yeats (see for instance B's mention of the stench that comes off his rotting stump), we would be extremely grateful to see these two flawed bodies unite into a mutually caring, complementary couple, neutralise each other's deficiencies and disappear from view. On the contrary, they prove incapable of joining forces in any productive way, of collaborating efficiently to transcend their bodily limitations; yet while collaboration fails to happen in reality, it is fleetingly imagined in the central, climactic moment of the play, when A and B create the fiction of what their life together might be:

B: ... Of course if you wish me to look about me I shall. And if you care to push me about I shall try to describe the scene, as we go along.

A: You mean you would guide me? I wouldn't get lost any more?

B: Exactly. I would say, Easy, Billy, we're heading for a great muckheap, turn back and wheel left when I give you the word ... I see a round tin over there in the gutter, perhaps it's soup, or baked beans.

A: Baked beans! [He gets up, puts down fiddle and bowl on the stool and gropes towards B.] Where are you?

B: Here, dear fellow. [A lays hold of the chair and starts pushing it blindly.] Stop!
A: [Pushing the chair.] It's a gift! A gift!
B: Stop! [He strikes behind him with the pole.] (CDW 230)

The fiction they create collaboratively, and enjoy immensely, is the fiction of their collaboration. The configuration of the creative process is a familiar one in the Beckett canon: roles are distributed unevenly, with A cast as Listener, B as Storyteller, creating a whole landscape and tantalizing A with the prospect of that most coveted of delicacies, baked beans. Yet both A and B are equally necessary to the fictionalising process, which requires both a storyteller and an audience. The story produces immediate enjoyment, burlesquely metaphorised by the baked 
beans-it may not be terribly good, yet it provides a moment of pure, communal jouissance. But when A loses track of its fictional nature and attempts to act it out "for real" the story is interrupted abruptly and remains incomplete, a fragment of a Fragment.

Both Yeats and Beckett thus resort to the fable of the blind man and the lame man to challenge dominant modern representations of literary collaboration. While many modernist writers, among whom Yeats features prominently, were keen to experiment with new modes of collaborative writing and creating to respond to the demands of the expanding market of art and literature, both plays return instead to storytelling, a traditional mode of collaborative creation not aimed at the production of a finished, marketable product, but at immediate, shared enjoyment. With casts of disabled characters and strong undercurrents of queer eroticism, both plays thus point to literary creation as a potential site of resistance to modern expectations that bodies be coerced to serve the capitalist project of generalised productivity, including in the artistic field. More generally, I would argue that Beckett follows in Yeats's steps to offer an alternative paradigm of literary creation in general, as being by definition a collaborative process: an act of love, which involves an asymmetrical distribution of power and a degree of violence, and can only aim to produce fragments of stories forever unfinished, yet delectable. Parody, of course, is such an act of love and violence, and Beckett's parody of Yeats redoubles the story of the ill-assorted couple who fail to collaborate productively, producing only a "rough" approximation of a fiction, but have a high old time of it.

\section{Notes}

1. The play was first published in July 1924 in literary journals The Criterion and The Dial, and later that year in The Cat and the Moon and Certain Poems, published by Cuala Press. It was first performed by the Dublin Drama League at the Abbey Theatre in 1926. Yeats revised the play in 1930-31, and it appeared again in print with an expanded ending in Wheels and Butterflies in 1934.

2. This theme is already present in De la Vigne and fully developed in Synge's The Well of the Saints, in which the two blind beggars, having once been cured and experienced the horror of work, subversively refuse to be cured again and are consequently expelled from the outraged community and sent to their probable death.

3. The episode rewrites the story of Christophe, the Christ-bearer.

4. Critics who have pointed out these similarities include Carol Fisher Sorgenfrei (97), C. J. Ackerly and S. E. Gontarski (489) and Julie Bates (155).

\section{References}

Ackerly, C. J. and S. E. Gontarski. The Grove Companion to Samuel Beckett: A Reader's Guide to His Works, Life, and Thought. New York: Grove Press, 2004.

Bates, Julie. Beckett's Art of Salvage. Writing and Material Imagination, 1932-1987. Cambridge: Cambridge University Press, 2017.

Beckett, Samuel. Rough for Theatre I. Complete Dramatic Works, London: Faber and Faber, 1986. 
Davis, Lennard J. Bending Over Backwards. New York: NYU Press, 2002.

Frazier, Adrian. "Queering the Irish Renaissance. The Masculinities of Moore, Martyn and Yeats." Gender and Sexuality in Modern Ireland, Eds. Anthony Bradley and Maryann Giananiella Vaniulis. Amhers: University of Massachusetts Press, 1997, 8-38.

Lyons, F. S. L. “George Moore and Edward Martyn." Hermathena, no. 98, Spring 1964, 9-32.

Knowlson, James. Damned to Fame. The Life of Samuel Beckett (1966). New York: Touchstone, 1997.

Sato, Yoko. "Fenollosa's Manuscript of Kikazu Zato: The Japanese Source of Yeats's The Cat and the Moon." Journal of Irish Studies, vol. 30, Oct 2015, 27-38.

Sorgenfrei, Carol Fisher. "Beckett and Japanese Theatre." Theatre Intercontinental. Forms, Functions, Correspondences, Eds. C. C. Barfoot and Cobi Bordewijk, Amsterdam and Atlanta: GA, Rodopi, 1993, 83-100.

Yeats, W. B. The Variorum Edition of the Plays of W. B. Yeats, Eds. by Russell King Alspach and Catharine C. Alspach, London and Basingstoke: Macmillan, 1966.

Recebido em: 15/11/2018

Aceito em: 03/04/2018 